\title{
Adaptační procesy a jejich aktéři v modernizující se Evropě*
}

\author{
LUĎA KLUSÁKOVÁ** A KOL.
}

Adapting to European Modernization: Processes and their Actors

\begin{abstract}
The research team of the project "History of Adaptation" seaks shared understanding of key concepts centred around four research perspectives: 1) long-term development and ancient historical roots of contemporary adaptation strategies that build on memory, tradition, respect for historicity, recognising the relatively recent emergence of the concept of cultural heritage and its protection; 2 ) the city as a dominant social framework, e.g. from the perspective of commodified historicity; 3 ) the politics of expertise and power, focusing on the relationships between the production of knowledge and governance, the growing importance and adaption of the role of experts and technocrats in the professionalisation of social management as well; 4) the emic perspective of contemporary social actors - individuals or groups. In the first part of the article, the authors outline these four perspectives, while in the latter part, organized as a roundtable, they situate the key concepts in the context of their disciplines and open a discussion to be continued throughout the project.
\end{abstract}

Keywords: adaptation; modernization; expert governance; technocracy; city; heritage; memory; identity

DOI: $10.14712 / 23363525.2019 .6$

\section{Úvod o konstrukci projektu}

Při studiu historie adaptačních procesů vycházíme z předpokladu, že existovaly a existují vnější tlaky a podněty vyvolávající reakce společnosti, respektive jednotlivých aktérů, které je třeba identifikovat, analyzovat a pojmenovat. Opřeme-li se o Eliasovu figurativní sociologii, která svého času velmi inspirovala kulturně historický výzkum, můžeme sledovat vývoj jakékoliv společnosti jako vytvářející tlaky na jednotlivce, komunity či společenství v různých figuracích [Elias 1978], která jim mohou rozličnou formou a měrou vzdorovat [Crossing Frontiers, Resisting Identities 2010]. Optika adaptace představuje opačnou perspektivu. Přijímání tlaků jako výzev, na něž je možné či nutné reagovat různou formou přizpůsobení se nové situaci.

Pro výrazně interdisciplinární tým může být úskalím vzájemné spolupráce hluchota vycházející z recipročního neporozumění pojmům, kterou společenské vědy stále ještě nepřekonaly [Burke 1992; Šubrt 2008]. Ve snaze vyvarovat se nedorozumění a ujasnit si

\footnotetext{
" Projekt „Kreativita a adaptabilita jako předpoklad úspěchu Evropy v propojeném světě podporují operační fondy EU, jeho nositelem je Filozofická fakulta Univerzity Karlovy. Výzkum je veden ve třech výzkumných programech koncipovaných pro mnohooborové výzkumné týmy. Historická perspektiva se projevuje ve všech programech, ale v rámci druhého programu zkoumajícího procesy sociálně kulturní adaptace vznikl vlastní prostor pro mezioborový výzkum historie adaptačních procesů.

** Prof. PhDr. Lud’a Klusáková, CSc., KREAS / Filozofická fakulta, Univerzita Karlova, nám. Jana Palacha 2, 11638 Praha 1. E-mail: luda.klusakova@ff.cuni.cz.
} 
chápání pojmů a přístupů k problematice, která již v použitém pojmosloví ohlašuje procesuální chápání jevo̊ jako součást či výsledek vyjednávání, se autoři rozhodli pro nekonvenční formát pozičního dokumentu jako svého druhu záznam diskuze. Kulatý stůl v písemné podobě se zaměří na prrístup ke studiu adaptačních strategií v různých společenských vazbách, v historické a komparativní perspektivě tak, jak se objevovaly v modernizující se (a také poměstštující se) společnosti, tj. od raného novověku do současnosti. Svůj zájem neomezujeme ani prostorově, ani měřítkem analýzy: zkoumáme strategie jednotlivců, skupin aktérů nebo institucí v lokálních, regionálních, národních i nadnárodních kontextech.

Naším záměrem v tomto projektu je vést analýzu historie adaptačních procesů ze čtyř perspektiv:

1) Z perspektivy dlouhodobého vývoje, kdy výzkum poukáže na hluboké historické kořeny současných strategií operujících s pamětí, tradicí, úctou k historicitě, sahající do starověku, ačkoliv koncept kulturního dědictví a jeho ochrany je poměrně nový fenomén. Reprezentace antického dědictví má v tomto kontextu zcela specifický význam pro společnosti $\mathrm{v}$ evropských městech/zemích od počátečních projevů modernizace až do současnosti a ve všech kontextech poukazuje na transfery kulturních hodnot v prostoru a čase. Práce s pamětí se zintenzivnila v raném novověku a stala se rafinovanou, operující na mnoha úrovních a s různými motivacemi pro revalorizaci či revizi interpretace minulosti, jež postupně dospěla k formulaci konceptu kulturního dědictví a vnímání jeho hmotné a nehmotné formy.

2) Z perspektivy města jakožto dominantního sociálního rámce. Města jako výkladní skříně a prestižního reprezentativního prostoru společnosti. Z hlediska historicity, která je využívána v rozvojových strategiích měst a regionálních celků i při interpretacích kulturního dědictví na více rozhodovacích úrovních. Argumentace historickým příkladem při rozhodování o osudech města, jeho správě, řízení, zásazích do zástavby má dlouhou tradici (historii). Větší a velká města se složitou identitou poutají pozornost badatelů i veřejnosti daleko více než mnohem početnější a pro evropský urbanismus typická města malá a miniaturní. Jejich využívání kulturního dědictví v historické perspektivě a při artikulování rozvojových strategií v současnosti i v kontrastu k regionálním centrům a metropolím nás bude zajímat především.

3) Z hlediska politiky expertízy a moci, která sleduje vztah mezi produkcí vědění a vládnutím. Zajímají nás proměny forem kontroly, plánování a regulace, ale také růst významu a adaptace role expertů a technokratů v profesionalizaci řízení společnosti. Rovněž tyto pojmy stvořené společností dvacátého století lze aplikovat ve starších historických obdobích, pokud dokážeme překonat nebezpečí anachronismu.

4) Z (emické) perspektivy současného aktéra, jednotlivce či skupiny jednotlivců, kteří nejsou technokraty, ale přesto vstupují do děje se svými osobními zkušenostmi, osobní a rodinnou historií, s předsudky, obavami, pragmatičností a vypočítavostí a harmonizují, nebo naopak zpochybňují to, co jim přinášejí technokraté, politický aparát, globální vývojové trendy i to, co poskytuje dlouhodobá historie. Osobní angažovanost individuálních aktérů je někdy náhodným, překvapivým, někdy předvídatelným činitelem způsobujícím sociální změnu a je též jedním ze subjektů, který sledovanému dění dává smysl. 
Výzkum v každé z uvedených oblastí je předmětem specializovaných vědních disciplín či subdisciplín se specifickým úhlem pohledu, pojmovým aparátem a metodologickými postupy. Koncept adaptačních procesů lze aplikovat $\mathrm{v}$ každé $\mathrm{z}$ nich a využitelnost poznatků jednotlivých disciplín a subdisciplín roste s pochopením rozsahu, v jakém je v nich využíván.

\section{Historie a archeologie ve veřejném prostoru}

Náš výzkum adaptačních procesů se velmi úzce dotýká použivání historie a archeologie ve veřejném prostoru, s nímž souvisí i osamostatnění se tzv. heritage studies. Ve spojení kolektivních praktik s reprezentacemi, které slova a texty reflektují, se vytvářejí zkušenosti, jež dosavadní výzkum ještě nedokázal vysvětlit. Tento typ zkoumání totiž dnes již nelze provádět $\mathrm{v}$ lokálním nebo národním rámci, ale je zapotřebí se zaměřit na přenos identit, konstrukci a akceptování (sebe)identifikací, na transnacionální transfery, v nichž se různé významy a identity nepřenášejí v nezměněné podobě, ale procházejí procesem osvojování, v němž se původní záměry podstatně mění a získávají nové motivy a funkce (viz např́íklad transfer technologií posledních třiceti let nebo současnou migrační krizi). Je zde tak vidět, že výzkum sociálně-kulturní adaptace je klíčovým předpokladem porozumění dnešní historické konstelaci a potažmo předpokladem úspěchu Evropy v propojeném světě. V podstatě nelze adaptaci pojímat jen jako „automatickou“ reakci systému na vnitřní či vnější podněty, ale je zapotřebí ji vysvětlovat v návaznosti na důkladnou znalost životního světa lidí - hodnot, zkušeností zneuznání a představ o naplněném životě, jak se utvářely $\mathrm{v}$ čase.

Kromě dlouhodobého sledování adaptačních vzorců tematizujeme identifikační roli historických př́kladů a jejich transformace do pozice kulturního dědictví. V tomto kontextu mají naprosto výjimečný význam archeologické nálezy z období antiky a jejich interpretace $\mathrm{v}$ historickém kontextu. Kromě mnohostranných manifestací je $\mathrm{v}$ centru pozornosti archeologů v našem týmu také studium adaptačních strategií skrze archeologické bádání v oblastech, které jsou známé jako kontinuálně „sporná územi“ (contested periphery) [Cline 2008] a z nichž zejména oblast východoegejského/západoanatolského pomezí v době bronzové, charakterizované přesuny obyvatel oběma směry, je v poslední době předmětem soustředěného mezinárodního bádání [Mountjoy 1998; Girella - Pavúk 2016]. Není to náhodně vybraný region, protože i v současné situaci migračních pohybů a kulturních střetů se tato oblast stává klíčovým územím. Výzkum jeho historických zkušeností, souvisejících s procesy hybridizace a „zaplétání se“ (entanglement), viz např. Bhabha [1994] a Stockhammer [2013], a obecně s reakcí místních na príchod nových skupin obyvatelstva a nových civilizačních vlivů, jež je možno dedukovat $\mathrm{z}$ archeologické (a částečně $\mathrm{i}$ textové a jazykové) stopy, tedy promlouvá rovněž k naléhavým otázkám dneška. Dosavadní výzkum, spolu s postkoloniální teorií [Gosden 2004], naznačuje, že změny nemohly být výsledkem pasivního přejímání, ale naopak je třeba předpokládat aktivní a kreativní príístup místních populací k novým impulzům (materiální kultuře, technologickým inovacím, kulturním a náboženským představám atd. nově př́íchozích společenstev, avšak též k vlivu klimatických změn). Předpokládáme, že náš výzkum může účinně rozvinout tento směr bádání právě zaměřením na vývoj daného území z hlediska různých adaptačních strategií, které vedly ke vzniku nové kultury i nového uspořádání sil, jež však navazuje rovněž na 
předcházející obchodní partnerství. V opačném směru přinesou výsledky tohoto výzkumu i nový vhled do otázky evropských hranic a jejich prostupnosti, a to zejména na pomezí dnešního Recka a Turecka.

Ve všech těchto souvislostech se otevírá prostor pro zkoumání předpokladi̊ kreativity a adaptability $\mathrm{v}$ současném světě, se zaměřením zejména na způsoby, jakými aktéři spojovali či spojují určité významy ve své praxi, když jednali a jednají ve světě, který je pro ně symbolicky smysluplný. Teprve když dáme do souvislosti proměnu kódů (znaků, slov, významových souvislostí) s jejich uplatněním ve společenské praxi (tedy tím, jak aktéři chápou význam toho, co prožívají), budeme schopni vysvětlit, proč se prosadí jedny kolektivní reprezentace (např. nacionalistické, demokratické apod.) a neprosadí jiné (např. dynastické apod.).

\section{Kulturní dědictví, identifikace a reprezentace jako adaptační strategie}

Koncept kulturního dědictví (cultural heritage) je v historickém výzkumu poměrně nový, nabývá širokého významu, když nahrazuje koncept identity, paměti i komemorace. Pojem se zformoval v anglofonním a frankofonním prostředí [Delafons 1997; Audrerie 1997]. Zvláště v anglosaském prostředí se od 80. let minulého století rozvíjí široce založené bádání na poli tzv. Heritage Studies, které se zabývá kulturním dědictvím především z konstruktivistické perspektivy. Od památek přesouvá pozornost k reprezentacím, resp. k významům, které nejsou objektům inherentní, nýbrž jsou jim sociálně připisovány. Dědictví chápe jako selektivní procesy, jimiž společnosti přetvářejí minulost a její pozůstatky ve zdroj pro přítomné cíle a budoucí projekty podle svých současných přání a představ [Graham - Howard ed. 2008]. Z konceptuálního hlediska je zkoumá jako diskurzy o dědictví či soubory praxí, jež utvářejí určité představy o tomto dědictví a jeho významech, přičemž se opírají o expertní vědění, pomáhají reprodukovat hegemonní koncepce společnosti, vymezovat sociální hranice a doplňovat mechanismy sociální inkluze a exkluze. Pozornost se upírá jednak k dekonstrukci „autorizovaných diskurzů o dědictví“ [Smith 2006], a zároveň ke studiu konfliktů a tenzí, které se k dědictví vztahují, např. ve vazbě na postkoloniální kritiku, téma nedostatečné reprezentace znevýhodněných skupin a vrstev či nerovného přístupu k dědictví jako společenskému zdroji. Zároveň se snaží uchopit kulturní dědictví jako potenciální nástroj emancipace či subverze. Samotné dějiny kulturního dědictví je pak vhodnější pojímat spíše jako dějiny mocenských vztahů, jež operují a zároveň jsou formovány prostřednictvím kulturního dědictví [Harvey 2008]. V této perspektivě lze kulturní dědictví chápat nejen jako zdroj či nástroj adaptace různých společností či civilizací, ale obecněji jako strategii, resp. jeden z adaptačních mechanismů, jež se podílí na formování, stabilizaci, ale také transformaci kolektivů i prostorů nejrůznějšího typu. $\mathrm{V}$ současnosti je pojem spojen především s politikou UNESCO a EU a stal se nástrojem kulturní politiky v národním i mezinárodním měřítku: European Heritage Label; seznam světového kulturního dědictví UNESCO [Labadi - Long 2010]. Proto představuje konceptualizace evropského kulturního dědictví jako substituce evropské identity důležité téma akademického výzkumu [Sonkoly 2015; Bokova 2013].

Analýza identifikačních procesů používajících instrumentálně kulturní dědictví bude velmi často pracovat s př́klady situovanými do měst. Hlavní města, metropole a regionální centra jsou v těchto výzkumech studována nejčastěji. Čas od času se v hlavním proudu 
urbánních studií objevuje téma malého města, jemuž je přiznána priorita početně převažujícího sídelního typu mezi evropskými městy. Ačkoliv jak sociologické, tak historické výzkumy prokázaly prríspěvek společností malých měst $\mathrm{k}$ zavedení různých inovací, ve veřejném diskurzu jsou malá města vnímána jako konzervativní, lpící na tradicích a odolávající změně. $V$ diskurzu urbánních studií je malé město definováno několika kritérii: počtem obyvatel při poměrně značném rozptylu určujícím limit mezi malým a středně velkým městem; organizací prostoru a vybaveností; městskými službami a funkcemi; př́ípadně statutem. Z našeho dosavadního výzkumu vychází jako efektivnější pro komparaci definovat město jeho funkcemi.

$\mathrm{V}$ diskurzu úřadů spravujících města a různě definované a pojmenované regiony v posledních letech získaly pevné místo strategie, plány a projekty regionálního rozvoje. Ty řeší sociální a ekonomické cíle, jako snížení nezaměstnanosti, hledání cest k dosažení konkurenceschopnosti, zvýšení inovativnosti, zlepšení kvality života [Blažek - Uhlír 2011: 1319]. Pojem strategie v názvu a skloňovaný ve všech pádech a různých kontextech nenajdeme běžně, pokud ano, tak opět výhradně v ekonomickém kontextu jako nástroj, s jehož pomocí je možné nabídnout dlouhodobou vizi, perspektivu pro rozvoj. Založení muzea venkova, asociace pro prezentaci tradičních řemesel, modelu staroslovanské vesnice má mít ve výsledku ekonomický efekt - zvýšit turismus [Kłodzinski 2006, passim a s. 36].

Někteří geografové a sociologové si již dříve všimli strategií využívajících kulturní dědictví jako marketingový a identifikační nástroj. Mezi prvními najdeme výzkum francouzského sociologa Bernarda Kaysera, jenž analyzoval situaci venkovských regionů západní Evropy a USA koncem dvacátého století. V současnosti se nabízí jeho výsledky uchopit jako dokumentaci procesu, který je v některých částech Evropy historií, zatímco $\mathrm{v}$ jiných částech právě probíhá. Kayser popisoval a analyzoval revoluci v hodnotách, jež pojmenoval renaissance rurale. Venkov, monde rurale, campagne profonde, vzdálený metropolím chápal nejen včetně vesnic a osad, ale i měst mnohdy velmi malých. Jeho a jejich znovuzrození byl pro něj proces, který má z definice pozitivní konotaci, jeho cílem je zlepšení všeobecné situace a úspěch [Kayser 1990]. Znovuzrození definoval jako žádoucí proces, jenž je výsledkem rozhodování a přijetí úspěšné strategie.

Nejen Kayserovu analýzu ,jeho současnosti“ můžeme číst jako historické svědectví a konfrontovat se situacemi o deset, dvacet či třicet let mladšími [Mainet 2011; Edouard 2008, 2012]. Bernard Kayser již koncem osmdesátých let spolu s Alainem Lefebvrem a Robertem Bourrem identifikovali festivalizaci jako úspěšnou strategii malých měst a na přelomu tisíciletí poukázali na významnou roli neo-rurálů při prezentaci regionální kultury [Lefebvre - Bourre 2000; Kayser 2001]. Využívání vztahu ke kulturnímu dědictví v zápasech o identifikaci společnosti malých měst si o něco později všimli geografové [Périgois 2008]. Povšimli si rovněž funkce kulturních aktivit [Sibertin-Blanc 2008] a opět festivalů, respektive slavností [Gravari-Barbas 2009]. Tyto geografické výzkumy se odehrávaly nezávisle na starším sociologickém výzkumu a často bez odkazu na práci historiků, kteří se podíleli na popularizaci historie a institucionalizaci kulturního dědictví. Francouzské teoretické a empirické výzkumy nabízejí otázky a motivují k různě koncipovaným komparacím naprríč Evropou [Klusáková 2008; Klusáková 2017]. Poukazují také na významnou roli expertů při artikulování strategií a jejich realizaci v minulosti i v současnosti. 


\section{Adaptace, adaptabilita, adaptační prostor a expertní řízení}

Významný podnět $\mathrm{k}$ formulaci tohoto projektu vzešel od týmu zabývajícího se problematikou expertního řízení společnosti ve dvacátém století. V diskuzi toto téma nabylo mnohem hlubší historickou perspektivu. Z pohledu historiků raného novověku odvozujeme počátky tohoto jevu přinejmenším od emancipačních snah městských institucí a působení expertů v nejrůznějších odvětvích od renesance. Hypoteticky předpokládáme, že respekt k expertům vyrůstá z prestiže specializovaného vzdělání, emancipace a profesionalizace často nově vznikajících oborů.

Členové týmu, jež spojuje zájem o studium „Technokracie a adaptability v Československu 20. století, vidí společné východisko v konceptu „organizované modernity“ [Wagner 1995; Wagner - Strath 2017], který představuje spojující osu mezi jednotlivými časovými periodami.

Charakteristické rysy organizované modernity spočívají ve vyšší míře organizovanosti a v rozsáhlejším zasahování veřejné či státní moci do oblastí, jež byly dříve v souladu s liberálními dogmaty vyhrazeny soukromé sfére a iniciativě jednotlivců. Sám Wagner tento proces charakterizuje následovně: „Liberální praktiky se zakládají na svobodné dohodě a asociování množství jednotlivých aktérů při určení míry a obsahu kolektivních uspořádání ve společnosti. Pokud je tato definice akceptována, můžeme ukázat, jak liberální praktiky od devadesátých let devatenáctého století do sedmdesátých let století dvacátého ztrácí na významu. Oslabují ve prospěch organizovaných praktik, které vyžadují koalice skupin podle sociálních kritérií před rozhodnutím o kolektivních uspořádáních a jejich provedením. Vůdci domněle homogenního členstva jeho jménem mluví a jednají; reprezentují jej“ [Wagner 1995: 112-113].

Koncept organizované modernity za prvé usnadňuje úspěšné včlenění kolektivistickými argumenty ospravedlňovaných nároků směřujících ke stupňování různých forem ovládání jednotlivců, jež ideologická fundace liberální modernity označovala jako nepřípustné, resp. jako nepřirozené, do vývojového rámce modernity a jejích různých variant, jež se rozvinuly na evropském kontinentě v průběhu 20. století.

Za druhé ona vyšší míra organizovanosti implikuje úlohu racionálního řízení společenského celku, v němž vystupuje do popředí aktivní úloha vědců (sociálních inženýrů), což označujeme jako „kreativní moc expertního diskurzu“. Odborník jako producent vědění nastoluje kauzální vysvětlení jevů, jež jsou v dané době považovány za nežádoucí či problémové, a na základě konkrétní konstrukce kauzality pak dovozuje adekvátní řešení. Marc Blyth v tomto směru výmluvně konstatuje: „Aktéři musí vést spory, diagnostikovat, přesvědčovat, ba vnucovat druhým svoje vysvětlení toho, co je krize. Teprve potom může nějaká kolektivní akce získat smysluplnou institucionální formu“ [Blyth 2002: 9-10].

Klíčovými aktéry na tomto místě nejsou jen osoby v hierarchiích politické moci, nýbrž i ti, ba zvláště ti, kteří produkují expertizu, s níž politická reprezentace dále pracuje. Výzkum se proto bude úzce věnovat zpo̊sobům využívání expertního vědění v moderním vládnutí. Výzkum by měl nahlížet na technokracii a expertní vládnutí jako na rozporuplné historické fenomény, které se vzpírají jednoznačnému zařazení na škále mezi autoritářstvím a demokracií. Zároveň s tím by měl na dostatečně reprezentativní pramenné základně demonstrovat rozpornost scientistických postupů uchopování společenské reality a jejich nároku na depolitizované a neideologické řešení společenských 
rozporů a problémů. Perspektiva zahrnující dlouhé období zhruba jednoho století umožňuje demonstrovat dobovou podmíněnost a proměny toho, co je $\mathrm{v}$ dané chvíli považováno za racionální uspořádání společenského celku. Ačkoliv můžeme aplikaci konceptu expertního vědění vnímat jako naprostý anachronismus, aktéři spojení s propagací vědění se projevovali jako svého druhu „sociální inženýři“ již v konání a názorech reprezentantů osvícenství, ba možná ještě dříve, právě mezi intelektuály doby humanismu a renesance.

$\mathrm{Z}$ pohledu urbánních historiků v týmu jsou záměry a cíle inovátorů, expertů či technokratů spojeny různými způsoby s městy, s městskou společností a městskou kulturou. $\mathrm{K}$ evropskému městu, jež je produktem evropské kultury, je vázána představa o stabilitě formy, ale také schopnost vytvářet kulturu [Kaelble 2000], otevřenost a inovativnost [Clark 2009], strategické užívání hmotného i nehmotného kulturního dědictví (tangible and intangible cultural heritage). Město reaguje na všechny civilizační střety nejen při formování nových státních útvarů a následně státních, národních nebo kulturních identit.

Pojem technokracie (přes svou značnou interpretační flexibilitu) v literatuře souvisí s organizačními principy a úsilím o systematické, racionální a efektivní rízení stále komplexnějších vztahů uvnitř moderní, technologické společnosti [Radeali 2017]. Charakteristickým rysem technokratického, expertního vládnutí je nepochybně plánování (měst, ale potažmo i jejich paměti - kulturního dědictví), které ve své podstatě představuje ex-ante formu adaptační strategie. Ta byla ovšem historicky (v kontextu formování organizované modernity) limitována omezenou schopností predikce a anticipace budoucích výzev mocenskými hierarchiemi objektivizovaným a aplikovaným expertním věděním, které následně podkopávalo legitimizační potenciál plánování jako takového. Výsledkem této systemické krize se zdá být od sedmdesátých let 20. století v evropském kontextu pozorovatelný nárůst participativních modelů řízení i plánování, které ve své podstatě mají sloužit demokratizaci (individualizaci) a udržitelnosti zvolených řešení [Oldenziel - Vleuten 2017]. Podobným procesem procházela také diskuze o kulturním dědictví, které se z úzce top-down (tedy technokraticky) definovaného elitistického projektu „civilizační“ paměti [Falser 2015] stalo nástrojem emancipace v rámci památkového diskurzu marginalizovaných skupin obyvatelstva, viz např. decentralizace konstrukce „Evropského“ dědictví od devadesátých let [Calligaro 2013].

Právě participativní modely řízení a péče o kulturní dědictví v městském prostoru měly přispět $\mathrm{k}$ nárůstu sociální koheze a resilience - prostřednictvím diverzifikace, přiblížení skutečným „uživatelům“ a zvýšení jejich identifikace s urbánním prostorem a významy, které kulturní dědictví reprezentuje. Na poli kulturního dědictví je ovšem tento proces do jisté míry ohrožován dosud v oboru nepř́iliš patrnou „technifikací - kdy v kontextu „herigitization“ dochází ke zpětnému odcizení „dědictvi“ a jeho původních nositelů/uživatelů prostřednictvím digitálních technologií, sofistikovaných konzervačních a prezentačních metod a v neposlední ŕadě ekonomických a marketingových instrumentárií komodifikace orientované na zisk [Silverman - Waterton - Watson 2017].

Když překročíme hranice svých úzkých specializací a kontextualizujeme jevy a procesy, které projekt zkoumá, zjistíme, že se tak či onak vztahují k městské civilizaci. Odehrávají se ve městech, jejich aktéri vyšli z městských institucí. Žádoucí postupy, technologie, organizace práce, životní styl jsou inspirované městem. Zkoumané procesy adaptace se uskutečňují právě v prostředí měst. Města jako taková jsou svým typem symptomatická pro svůj civilizační okruh. $\mathrm{V}$ evropském kontextu jsou nejen společenskou silou a zdrojem 
inovativních myšlenek, ale také kulturním dědictvím, přičemž mají i charakter „uzavřeného“ systému, který si udržuje svou identitu v aktivní komunikaci s okolím. Města se neustále mění, přesto vykazují stabilitu formy a odolnost. Koncept odolného města (resilient city), které je schopno čelit rizikům (např. klimatickým změnám) či katastrofám, absorbovat jejich účinky a zotavit se $\mathrm{z}$ nich, se stalo novým strategickým termínem světového urbanismu. V historické perspektivě však představuje jen recentní výraz pro adaptabilitu měst ve vztahu k výzvám společenského a př́rodního původu. Vedle infrastruktur či ekonomiky patří k zásadním pilíruom urbánní odolnosti sociální odolnost [Jha - Miner Stanton-Geddes (ed.) 2013]. Otevírá se otázka, jakou roli zde může hrát, a v minulosti hrálo, kulturní dědictví, které je často definováno jako důležitý zdroj pro dosahování cílů v politické, sociální a ekonomické rovině, např. sociální koheze a inkluze, občanské identity, přináležitosti s místem (sense of place, place attachment), a v neposlední řadě proměny míst pro turistické a jiné trhy [Ashworth - Graham - Tunbridge 2007]. Výzkum měst představuje velmi silný proud ve společenských vědách (v rámci oborů urbánní historie, sociologie, antropologie, geografie). Spojení konceptů inovativnosti [Hietala 1993; Clark 2009], kreativity a kultury [Florida 2005; Landry - Wood 2008; Landry 2008; Landry 2006] vygenerovalo nová témata ve společenskovědním výzkumu a nové výzvy pro interdisciplinaritu. Řešení současné krize by mělo být v novém urbanismu ve smyslu trendu winner-takes-all urbanism. Ačkoliv Florida revidoval své teze o jednoznačné moci kreativity a kreativců, nechává stranou pozornosti malá města. Čím větší město, tím jsou jeho obyvatelé rychlejší v přijímání inovací, otevřenější změnám a bohatší [Florida 2017: 6-19]. Jen města v kategorii superstar se dynamicky rozvíjejí, ta o něco menší stagnují a ta malá a nejmenší trpí [Florida 2017: 21-22]. Kreativita v jeho podání nesouvisí s kulturním dědictvím, ale s generováním bohatství. Můžeme dedukovat, že podle Floridy malá města nepřitahují tvořivé jedince a nevytvárí podle této teze rostoucí zisk. Jenže již dříve si někteří evropští autoři všimli činnosti kreativců v malých městech a na venkově, definovali typ neo-rurála a poukázali na roli kulturního dědictví v rozvojových strategiích měst a regionů [Keyser 1990, 2001; Chevalier 1993].

\section{Současný aktér a jeho každodennost}

Zejména antropologická perspektiva předpokládá, že kulturní dědictví vzniká zde a nyní, je stále znovu vytvářeno a reinterpretováno, utváří se v chování každého jedince a je situačně podmíněno. Souvisí s pamětí, genealogií, sociální i osobní zkušeností. Jestliže Maurice Halbwachs zdůrazňuje společenskou pamět jako kolektivní produkt, rríká tím současně, že je vyjednávána a konstruována v dialogu jednotlivců a společenských skupin [Halbwachs 1952, 1980]. Poznání způsobů a pravidel jejího konstruování je procesem, kdy výzkumník interpretuje individuální akty probíhající v nejrůzněji uspořádaných skupinách a rozkrývá jejich jednání. Zejména v 70. a 80. letech představili antropologové, historici a sociologové vliv národotvorných procesů na utváření sociální paměti. Ukázali, jak adaptace na nové společenské podmínky vedla k vytvoření fenoménu národních dějin a ke vzniku teorií o etnických společnostech a jejich vývoji. Ernest Gellner zejména na evropských př́kladech demonstroval mechanismy vytváření evropských kulturních dědictví a fenoménu vzniku masové kultury, jehož součástí se stanou i lokální zvyky a obyčeje [Gellner 1983, 1997], Benedict Anderson techniky šíření informací a poselství, které 
umožňovaly přetvářet myšlení lidí [Anderson 1983] a Eric Hobsbawm později historické kořeny řady těchto konceptů [Hobsbawm 1991]. Miroslav Hroch konkretizoval toto téma na střední Evropu a malé národy [Hroch 1985]. Uvedená díla předkládají tezi, že ve světě národů a nacionalismů existuje mnoho kulturních dědictví, jež jsou produkty procesů vytvořených jako reakce na změny sociálních situací $\mathrm{v}$ procesu modernizace a vzniku občanské společnosti. Akcentuje se v nich role národních států a jejich elit, které jsou pro nás jako sociálně organizační jednotky významné dodnes a jejich vliv na to, co je a co není pokládáno za kulturní dědictví, je kontinuálně významný. Zároveň však Ernest Gellner např́ílad v díle Jazyk a samota ukázal, že jakkoli národní kulturní dědictví působí jako kolektivní výtvor, jednotlivci se adaptovali na kulturní podněty a tlaky individuálně a někteří své vlastní kulturní dědictví a vlastní rodinnou či individuální pamět do národního kulturního dědictví nezapouzdřili [Gellner 2005].

S úvahou o vynalézání vlastní historie souvisí snaha zodpovědět otázku, jak vznikala a působila $\mathrm{v}$ konstrukci vlastního kulturního dědictví konceptualizace těch, co stáli mimo svůj národ. Teze rozpracovaná v díle Edwarda Saida, že „ti druzí, mimo vlastní skupiny, hrají významnou úlohu při formulování vlastního sebeobrazu [Said 1978], byla z perspektivy západní Evropy versus Orientu přenesena do širších dimenzí vztahu Evropy a neevropského světa v pracích Erica Wolfa [Wolf 1982] nebo Adama Kupera [Kuper 1988].

Téma kulturního dědictví a jeho adaptační funkce má celou řadu podob. Vedle národních modifikací badatelská obec zejména v 80 . a 90 . letech 20 . století stále zřetelněji vnímá, že vztah „my a oni“ začíná vzhledem ke globalizačním procesům podléhat změně. Zejména antropologie mění v této době svůj konceptuální a metodologický aparát. Na jedné straně například prostřednictvím Arjuna Appaduraie studuje společenské a kulturní přeměny vlivem globalizace [Appadurai 1996], současně prostřednictvím vlastních terénů reflektuje lokální projevy globálních jevi̊ a adaptuje po vzoru sociologa Rolanda Robertsona představu globálního sociálního prostoru [Robertson 1995]. I lokální situace jsou však velmi rozmanité vzhledem k diverzifikovaným skupinám, které lokální prostředí sdílejí. Inspiračním se zde stávají zejména imigrační skupiny, které reagují na lokální podněty odlišně než starousedlíci. Př́íklad George Marcuse studujícího společenskou elitu ze souostroví Toga $\mathrm{v}$ Londýně ukazuje, jak různé skupiny mohou vnímat vztahy mezi centrem a periferií diferencovaně a v souladu se svým vnímáním také velmi diferencovaně adaptovat své kulturní dědictví na nové prostředí [Marcus 1998]. Podobné otázce, ale v jiné dikci se věnuje též Frederik Barth př́i studiu Pákistánců a Afghánců v Norsku [Barth 1993] nebo Ulf Hannerz ve svých švédských i širších evropských př́kladech [Hannerz 1992, 1996]. Novou optikou se pak vrací k tématu národa a národního státu Michael Herzfeld, který konceptem cultural intimacy navazuje na Barthovské téma kulturních forem jako markeru - v pojetí Herzfelda obalu (cover) sociálních akcí [Herzfeld 1997].

Národ, stát a globální podněty jsou ovšem jen jedním z mnoha činitelů, které mohou pamět a kulturní dědictví jako adaptační mechanismus na lokální úrovni ovlivňovat. Normativní roli kulturního dědictví v kontextu malých francouzských měst rozpracoval např́ílad Marc Augé ve své teorii ne-míst [Augé 1992]. Jeho koncept zdůrazňuje myšlenku, že jednotlivé sociální skupiny, byt se cítí být součástí národního celku, budují na kulturním dědictví principy superiority, vlastní odlišnosti a jinakosti. Jednotlivá francouzská města zdůrazňují prostřednictvím kulturního dědictví svoji jedinečnost, unikátnost a nezastupitelnost. Prostřednictvím kulturního dědictví může být i to nejmenší město ve 
francouzském celku v něčem první. Zároveň se kulturním odkazem vážou k jednomu systému, jehož centrum reprezentuje Paříž. Symboly kulturního dědictví v Augého interpretaci mají jasnou prostorovou lokaci. Ty nejpodstatnější symboly jsou situovány tak, aby se s nimi mohlo setkávat co největší množství lidí. Kulturní dědictví je nutné v jeho interpretaci prožít. Jeho situačnost ale též umožňuje, že se mu lze vyhnout. Člověk může existovat v místech bez paměti, a tudíž i bez sociálních norem fixovaných kulturním dědictvím.

Marc Augé uvažuje o muzealizaci památek a jejich míjení lidskou ignorancí nebo jejich vytěsnění z lidské každodennosti (použije obraz silničních obchvatů, které se vyhýbají městským centrům, kde se sociální pamět koncentruje). Středoevropská zkušenost však nabízí vzhledem k migračním pohybům po druhé světové válce též zajímavé obrazy historických měst, v nichž žijí lidé bez sociální paměti nebo se sociální pamětí vázanou na jiné místo, než s kterým spojují svoji aktuální každodennost. Teprve postupně nové bydliště získává novou historii a kulturní dědictví dostává nové významy. Studiem tohoto jevu se zabývali počátkem 90. let antropologové v Jablonci nad Nisou, kde se sociální pamět dosídleného obyvatelstva a starousedlíků ještě po 50 letech diametrálně lišila a kde naopak další dimenzi této paměti přinášeli vysídlení obyvatelé, kteří si založili společné nové město na německém území [Müller - Uherek 1996]. Podobnému jevu se věnovala též Maruska Svasek, která studovala, tak jako před ní Libuše Volbrachtová, především vysídlené německé obyvatelstvo [Svasek 2012].

Nové otázky tématu adaptace a kulturního dědictví přinesla europeizace evropských národních společenství a jejich adaptace na konzumenty kulturního dědictví ze zahraničí. Etnografie vytvářené ve střední Evropě jsou velmi často zaměřeny na toto téma. $\mathrm{O}$ určité shrnutí se pokusili Michal Buchowski, Hana Červinková a Zdeněk Uherek v kolektivní monografii Rethinking Ethnography in Central Europe [Buchowski - Červinková - Uherek 2016], která již reflektuje fluiditu, situačnost a analytickou nejednoznačnost pojmů jako je národ, etnicita, kultura, identita. Pracuje v souladu s teoretickými závěry Rogerse Brubakera [Brubaker 2000, 2002] a autorů dalších prací z počátku 21. století, především s nativními pojmy, znalostmi a konstrukcemi, které aktéři projevují svým jednáním a promluvami. Na uvedenou publikaci pak navazuje kolektivní monografie Diversity and Local Contexts: Urban Space, Borders and Migration. Zejména texty Hany Červinkové a Juliet Golden [Červinková - Golden 2017] a Karoliny Koziury [Koziura 2017] se věnují manipulaci s kulturním dědictvím jako dobrou ochrannou známkou pro realizaci vlastních zájmů a obchodních záměrů. Zdeněk Uherek se ve stejné monografii soustředuje na téma kulturního dědictví, které je využíváno proti zájmům obyvatel města. Namísto aby ho mohli žít, musí se obyvatelé zkoumaného města adaptovat na nekomfortní prostředí naddimenzovaného turistického průmyslu [Uherek 2017].

Z výše uvedených antropologický textů je patrné, jak postupně prohlubované poznání obecných tendencí v antropologii směřuje k identifikaci individuálních zájmů a motivací. Kulturní dědictví se zde stává faktorem adaptačních procesů na společenské změny. Prostředí měst je významným katalyzátorem těchto adaptačních procesů ve stř̌edoevropských podmínkách přinejmenším od vrcholného stř̌edověku. Sledování současného dění v oblasti nakládání s minulostí a sociální pamětí ukazuje na diverzitu zájmů a pohnutek, které se teprve postupně podle pravidel kumulativních příčin stávají určitými směry a tendencemi přitakávajícími nebo odporujícími globálním trendům. Jak ukazují zkušenosti z výzkumů veřejného mínění v souvislosti se současnými migračními pohyby, velice často se adaptační 
mechanismy mohou měnit i na základě jednoho časově velmi krátkého podnětu, kterým může být fotografie utopeného chlapce [Borneman - Ghassem-Fachandi 2017], ale stejně tak i vidina zisku $\mathrm{z}$ turistického ruchu. Tyto náhlé, někdy i zkratovité změny však doprovázejí stereotypy a zažité adaptační mechanismy př̌edávané někdy po generace. Vzájemné prolínání těchto prvků v lidské každodennosti v projektu rozkrývá etnografická metoda.

\section{„Kulatý stůl“}

Ačkoliv jsme v úvodu popsali postup týmu ve čtyřech perspektivách, vnímáme intenzivně jejich průnik. Jak pro analýzu rozhodovacích procesů expertů, tak pro analýzu urbanizovaného prostředí i společenských procesů operujících s pamětí a kulturním dědictvím, tak pro jednání jednotlivých aktérů, diskuze v týmu označuje jako klíčový koncept adaptace, resp. adaptability v prostoru a v čase. Pojem adaptace by měl být chápán jakožto proces, nikoli výhradně staticky jako „stav věci“, míní Jan Randák. Dále navrhuje uvažovat procesy adaptace v kontextu šiř̌eji chápané ideologie. Vychází přitom mimo jiné z vlastního výzkumu věnovaného zvláštnímu školství $v$ době komunistické československé diktatury, $\mathrm{v}$ jeho rámci i odbornému expertnímu (pedagogicko-psychologického) vědění - konstitutivním rysem dobové defektologie byla představa (inspirovaná pavlovovskou fyziologií a psychologií) adaptace defektních jedinců na panující společensko-politické poměry budovaného socialismu. Tomuto procesu přitom nelze zjednodušeně rozumět jako pouhému popření individuality (defektního) jedince panující mocí, ale spíše coby stanovení podmínek, do nichž měl být aktér integrován, potažmo které měly jeho osobitost formovat a jež současně slibovaly garantovat proměnu jeho postavení ve smyslu společenského uznání.

Pro vyjednávání a rozhodování ve zkoumaných procesech má zásadní význam expertní diskurz, jenž stojí za rozhodováním expertů. Vítězslav Sommer konstatuje, že v centru zájmu výzkumu z perspektivy expertního rízení bude vztah expertízy a moci, resp. politika expertízy: $\mathrm{k}$ tématu adaptace podotýká, že existují různé podoby expertního vědění, které lze pojímat jako reakce na složitost moderní doby a světa, resp. jakožto způsoby, jak tuto komplexitu zvládnout. Do značné míry se bude jejich zájem dotýkat otázky vztahu mezi expertízou a demokracií, resp. otázky, kdo má právo vládnout a rozhodovat.

Pro Jakuba Rákosníka představuje výchozí tezi výzkumu, která má být prověřena, předpoklad existence organické vývojové linie sociálního a hospodářského plánování naprríč 20 . stoletím. Jejím prostřednictvím by mělo být vysvětleno, $v$ jaké míre pozdější socialistické plánování vstupovalo do již připraveného diskurzivního rámce, resp. nakolik šlo o cizorodý vnější import tzv. sovětských metod způsobující závažné systémové dysfunkce. Bude nutné v první linii popsat a analyzovat genezi, šíření a institucionální zakotvení expertního řízení, včetně terminologického rozboru vývoje (Begriffsgeschichte). Druhá linie se musí věnovat analýze dlouhodobého vývoje interakcí mezi expertním věděním a politickou mocí v prostoru českých zemí ve vztahu k ovlivňování populace, její kvantity, kvality, distribuce času jednotlivce a zabezpečení uznané úrovně kvality života.

Radka Šustrová zdůrazňuje, že technická a sociální racionalizace [Sachse 1993] $\mathrm{v}$ prostředí industriální společnosti předpokládá účelnou organizaci městského prostředí a života pracujících v tomto prostoru. Použití pojmu technokracie je možné jen v určitém časovém rámci. Např́ílad specifické podmínky 30. a 40. let neumožňovaly vládu expertů, avšak vyzdvihovaly expertízu jako nástroj politického rozhodování. Pozornost si 
zaslouží otázka kontinuit expertního řízení mezi divergentními politickými režimy, jež se vystř́idaly v českých zemích během pozdních 30 . let, až po tzv. lidovou demokracii. I přes prokazatelné prolínání a vzájemné ovlivňování politické sféry a expertního vědění je pro sledované období příznačná adaptace expertních kultur na nové politické poměry vyznačující se národocentrickou orientací expertízy a takřka apolitickým postojem vědecké obce a odborníků zejména v oblasti technické racionalizace.

Sledování kontinuit a diskontinuit ve vývoji expertního myšlení napříč politickými režimy ve 20. století, zvláště přes období nacistické okupace, doposud velmi omezeně zpracované, představuje jednu linii žádoucího výzkumu sledující rozmach technické racionalizace a tendence $\mathrm{k}$ technokratickému vládnutí v meziválečném období, který přinesl vybudování expertních struktur, jakými byly Sociální ústav Československé republiky, Psychotechnický ústav či Masarykova akademie práce. I přes proměnu institucionálního rámce tvořily expertní kapacity také v následujících dekádách zázemí pro maximální racionalizaci poměru pracovní nabídky a poptávky na trhu práce v silně industrializovaném prostředí. Okupace svým řízeným hospodářstvím a striktně organizovaným trhem práce vytvářela př́íhodné podmínky pro rozvoj studia lidské konstituce, psychotechniky a ekonomie práce. Referenčním rámcem byly nároky vědy a vědeckého poznání, jejichž možnosti za protektorátu se ukazují především ve srovnání s organizací vědy o práci $\mathrm{v}$ meziválečném i poválečném období.

Druhou linií je sociální, resp. biopolitická expertíza ve vývoji od 30. do 80. let. Studium populace, demografických ukazatelů, genetiky, zdravotních a sociálně-kulturních kontextů se od počátku 20. století realizovalo $\mathrm{z}$ velké části v rámci eugenické vědy, jež byla po zkušenosti s nacismem odmítnuta. Transformace expertního rámce do podoby „kvality populace“, obsahově ovšem pokrývá takřka identické pole myšlení o populaci, s jakým dříve pracovali stoupenci eugeniky. Kreativní práce expertů se po válce soustředila na sociální zázemí života populace a sociokulturně podmíněné defekty, jakými byla chudoba, kriminalita a ilegitimita.

Pro Matěje Spurného navazuje výzkum politiky státně socialistických zřízení opřený o učení marxismu-leninismu. Ve svých východiscích v šedesátých letech se setkávala s dominantním globálním techno-optimismem. Vedle klíčové role pozitivní vědy a jí podřízené techniky jako nástroje ekonomického růstu člověka spočíval tento průnik především $\mathrm{v}$ přesvědčení o pokroku coby nezpochybnitelném dobru, pro něž je třeba pracovat a které bude přinášet lidem čím dál tím větší svobodu a štěstí.

Dokud se (vedle přinejmenším generačně zakotvené, přetrvávající víry v nutnost překonávat dopady třídní společnosti) oba tyto pilíre, tedy ideál společenské funkce vědy a víra v pokrok, potkávaly s realitou a myšlenkovým světem velké části společnosti, byl státní socialismus navzdory všem přehmatům a dědictví stalinské minulosti schopen hájit svoji legitimitu.

Od pozdních šedesátých let a s novou silou především v osmdesátých letech ovšem můžeme i v prostředí státního socialismu sledovat krizi tohoto pojetí. Ta se projevovala formou posilování jeho kritiky, expertními př́ístupy, jež značně revidovaly dřívější technokratické plánování a zpochybnily jeho užitečnost, novou senzitivitou širokých vrstev obyvatelstva a nakonec stavem, kdy neotřesitelnou důvěru ve smysluplnost vlastních technokratických řešení ztráceli samotní vládnoucí technokraté. Načrtnutou hypotézu je ovšem třeba prověřit. 
Př́iklad utváření životního, především urbánního prostředí v Československu (v kontextu některých sousedních zemí) od šedesátých do osmdesátých let 20. století. Proměny urbanismu a obecně plánování městského prostředí, vztah k historickému dědictví a historickému městu, měnící se pojetí domova, ale i bytová politika a kultura, jež je možné vyčíst $\mathrm{z}$ expertních textů měnících se urbánních politik, zápasů o podobu rozvoje městské infrastruktury či osud tradiční městské zástavby i z nejrůznějších dobových reflexí. Provázanost konceptů expertního řízení, resilientního města a kulturního dědictví je podle Jiřího Janáče zcela evidentní a relevantní nejen pro náš projekt. Otázka, která v dosavadní diskuzi ještě nezazněla, připomíná Janáč, se týká role materiálních struktur a techniky. Ty vzhledem ke své omezené interpretační kapacitě (flexibilitě) představují důležité aktéry (chcete-li aktanty) v procesu artikulace krizí (výzev) či adaptačních strategií. At se jedná o faktory environmentální (momentálně populární klima), infrastrukturně-technické (např. zásobování vodou a energiemi) nebo architektonicky-urbanistické (socialistický či buržoazní urbanismus). Jejich fyzické parametry nepochybně ovlivňují jak formulaci problému (krize), tak prostřednictvím path dependency i zvolená řešení (viz např. nostalgické tendence na poli kulturního dědictví charakterizované př́klonem k ochraně socialistické architektury a umění). V tomto kontextu potom Janáč navrhuje tematizovat roli expertního řízení a rozvoje participativních metod řízení, zejména ve vztahu k technice a kulturnímu dědictví (nejen) ve městech.

Vztah adaptace a kulturního dědictví se konkretizuje v městském prostředí. Hana Červinková proto ukazuje, jak antropologie a s ní i historie pojímá kulturní dědictví jako prostor adaptace, resp. nástroj ve správě měst, a to $\mathrm{v}$ kontextu globálního soupeření měst a potřeby se zviditelňovat a vymezovat. Navrhuje tedy zaměřit se na instrumentální využívání kulturního dědictví a vnést do těchto analýz antropologickou perspektivu. Pro historii měst, architektury a urbanismu je sledování úsilí o jejich proměnu, nebo naopak o zachování historických hodnot opět polem pro vyjednávání a prosazování expertního názoru. Adaptabilita města byla a je zkoušena dnes a denně, shodují se Richard Biegel a Lud’a Klusáková s antropology a připomínají význam historické perspektivy.

Pro vrstvené hmotné kulturní dědictví ve městech nabízí Hana Červinková koncept contained memory (potlačovaná nebo kontrolovaná pamět') aplikovatelný i pro hmotné a nehmotné kulturní dědictví. Limitovaná výpovědní kapacita kulturního dědictví je výsledkem průběhu utváření jeho statutu. Dědictví reflektuje rozdílnou historii vzniku, ustavení a vývoje: at již je nejdříve zapomenuté, poté znovuobjevené, chtěné, nechtěné, nově konstruované. Jsou případy, kdy je redefinované, revalorizované, ale také sdílené ve dvou a více kulturách. Pro jeho ustavení a př́ípadnou institucionalizaci působí iniciativa shora či zdola spojená s participativními aktivitami.

Adaptační procesy navrhuje Jan Zdichynec odvozovat od proměn raně novověkých stř̌edoevropských měst, zejména měst menších a malých (v historické konsensuální definici mezi 2000-5000 obyvatel v rozmezí 16.-18. století). Domnívá se, že již v raném novověku byly přinejmenším ve středoevropském prostoru položeny základy mnoha pozdějších přístupů a procesů nakládání s tím, co dnes nazýváme kulturním dědictvím. Nejsou to jen elity ovládající městskou správu, ale adaptaci lze spatřovat také v konfesionalizaci, resp. specificky se lze zaměřit na kláštery, které přežívají i v protestantském prostředí (coby konkrétní příklad adaptace). Dobový diskurz ukazuje humanistické dějepisectví, např. městské kroniky s jejich společensko-výchovnými cíli („historia magistra vitae“). Městskou pamět 
vytvářely elity, avšak bylo by zajímavé zjistit, zda obyvatelé měst pohled elit sdíleli. Téma adaptačních procesů Zdichynec prověřuje výzkumem raně novověkých (menších) měst ležících na hranici regionů, ale zároveň na průsečíku vlivů. Východiskem mu je skvělé pramenné dochování měst ve Slezsku a Horní Lužici (Vratislav, Svídnice, Lubáň, Zhořelec, Žitava, Budyšín), zejména jejich bohatá kronikářská tradice v 16. až 18. století a další prameny úřední i privátní provenience. Dobře uchopitelný je zejména prostor menšího města - v 16. století kolem 5000 obyvatel (Lubáň, Budyšín, Žitava), které utváří vlastní pamět', má snad i vlastní politiku paměti, již určuje v prvé řadě prostřednictvím oficiálního kronikářství. To je dílem elit (členů městské rady, zejména purkmistrů či písařů, v menší míře duchovních a učitelů), zároveň prostupuje do dalších vrstev společnosti - množství zachovaných exemplářů jednotlivých kronik naznačuje zájem alespoň vzdělanějších a zámožnějších měštanů o dějiny svého města. Vypovídá do značné míry i o sdílené identitě měštanů, ukazuje, jakým zpơsobem vnímali prostor, který obývali, včetně jeho dějin. To lze prověřovat na tématech jako založení města, husitské pustošení, nástup reformace, vztahy k panovníkovi, postoje za stavovského povstání 1547 či 1618-1620, vnímání předání země Sasku (Horní a Dolní Lužice 1635) nebo Prusku (Slezsko 1742). Lokální historiografie humanistická i barokní, kronikářství, radní protokoly i prameny privátní povahy (diaria, korespondence) ukazují, jakým způsobem se měštané vyrovnávali se změnami, jimiž byli vystaveni. Kultura nápisů (v kostelích, zápisů v kostelních věžích), ikonografické prameny či divadelní představení, provozovaná nap̌r. v Žitavě nebo Zhořelci, pak ukazují pronikání témat udržovaných humanistickým historiografickým narativem i do obecnějšího povědomí. Vliv městské historiografie na utváření identity měst a měštanů (u vědomí složité sociální stratifikace předmoderního města) na prríkladech ze Svaté říše římské analyzovali Susanne Rau, Regula Schmidt či Klaus Graf; dosavadní výstupy byly shrnuty v rámci projektu Cuius regio, vedeného prof. Dick de Boerem na univerzitě v Arnhemu [Bobková - Zdichynec 2011]. Lze ji ovšem verifikovat rovněž pohledem na dosud spíše opomíjenou historiografii např. řádové provenience, tištěnou i rukopisnou. Rámec projektu možná přesáhne sledování vizuální stránky veřejných prostorů, ačkoliv tato má obrovský a stále rostoucí význam.

Z logiky tématu se navržený výzkum pohybuje mezi sociální historií, dějinami komunikace, církevní historií, ale zohledňuje také přístupy např. filologie a literární historie. Vzrušující výzvu, kterou nabízí účast v tomto projektu, představuje revize funkčnosti historického vědomí a dědictví v současném životě malých měst, která jsou zčásti ve společenském i hospodářském životě spíše marginalizována. Zde se lze inspirovat a konkrétní spolupráci rozvíjet zejména s polskými kolegy (Przemyslaw Wiszewski, Lucyna Harc); na příkladu hornolužických měst a městeček nebyl dosud např. život vylidňujících se, nový smysl existence hledajících městeček současného německo-polského pomezí zkoumán.

Další perspektivu vidí Jan Zdichynec v roli antiky v raně novověkém období a ve fenoménu nápisové kultury. Je třeba zdůraznit, že sledovaná středoevropská území spíše stojí stranou přímého dosahu antickým dědictvím, přesto je tu patrná snaha se vůči němu vymezit, i si je nějakým zpo̊sobem osvojit (údajně antické počátky měst, snaha počátky položit co nejhlouběji do minulosti). Argumentace antickými vzory v humanistickém dějepisectví je samozřejmá, ale roli tu má i mytologie, vztahování se k tomuto odkazu a zároveň též dědictví biblické.

Vztah k antice je téma, které se promítá po celé délce časové osy. Peter Pavúk poukázal v tomto kontextu na zajímavý paradox: ačkoliv panovalo obecné povědomí, že antika je 
základem evropského kulturního dědictví, v Praze na konci 19. století Národní muzeum nevyužilo možnost zakoupit antické sbírky, protože antické dědictví nebylo vnímáno jako dostatečně národní, české. Sbírka je dnes v Berlíně, zatímco Praha je nadále jediným hlavním městem v Evropě, které nemá vystavenou svou antickou sbírku [Dufková - Ondřejová 2006]. Nabízí se otázka, zda a jak se tento vztah proměnil a do jaké míry je antické dědictví dnes relevantní i pro Prahu. Pro náš výzkum identifikace a užívání kulturního dědictví, připomíná Luda Klusáková, je toto mnohovrstevnaté téma relevantní nejen pro města $\mathrm{v}$ regionech na jih od Limes Romanus. Navrhuje proto neomezovat otázku na metropole a budování velkých institucí národní kultury.

Prostor adaptace a roli sociální skupiny v rozhodujícím postavení vidí Tomáš Masař ve vývoji národních emancipačních hnutí „malých“ národů (Češi, Finové - Jan Zdichynec navrhuje doplnit Lužické Srby jako př́iklad národa, kde k plné emancipaci patrně nikdy nedošlo, srov. práce Leoše Šatavy) v průběhu „dlouhého 19. století“ [Hroch 2000]. $\mathrm{V}$ těchto procesech hrály velmi významnou roli poměrně úzké skupiny inteligence, které vytvářely nové národní elity, jejichž cílem byla konstrukce národních dějin a s nimi spjatého kulturního dědictví, s nimiž by se širší vrstvy národa následně identifikovaly. Přisvojení si specifického národního kulturního dědictví mělo probíhat i skrze adaptaci národních symbolů, at už vycházejícími právě z národní historie a mytologie, nebo nově zkonstruovanými. Zároveň se elity mnohdy snažily hledat inspiraci rovněž u jiných národů a národních hnutí a srovnávat, jakým způsobem se ony vypořádávají s vytvářením vlastního kulturního dědictví a zmíněným adaptováním národních symbolů. Při tomto procesu pak samozřejmě docházelo i ke snaze zasadit vlastní národní kulturu do širšího kontextu, zejména evropského. Na druhou stranu se nově vznikající národní elity mnohdy dostávaly do konfliktu s vládnoucími vrstvami a starými elitami, vůči nimž se z velké části vymezovaly. Docházelo pak ke střetům především v kulturní rovině, kdy se elity nově se formujících národních hnutí snažily prokázat životaschopnost a uměleckou hodnotu své národní kultury a následně také kodifikovat svůj národní jazyk a učinit ho zároveň i administrativním a vyučovacím jazykem.

Další rovinou pak byla snaha reprezentovat nově vznikající kulturní dědictví at už v rámci vlastního národa, nebo vičči okolnímu světu. Důležitou roli v této otázce pak hrála města (Praha, Helsinky), která byla centry národních hnutí. V nich se následně vytváŕí umělecké, vědecké nebo společenské instituce, které mají reprezentovat národní kulturní dědictví, s nimiž se následně má národ identifikovat a adaptovat tak myšlenky a ideologii národních hnutí.

Daniela Tinková odhaluje velké téma v nárůstu expertní moci a autority (odborného) vědění $\mathrm{v}$ symbióze $\mathrm{s}$ nárůstem moci státně byrokratické $\mathrm{v}$ procesu budování centralizované monarchie mezi osvícenstvím (cca 1740) a revolucí 1848/r.1861 (rámcově od pol. 18. do pol. 19. století), a to zejména na př́íladu medicíny (a příbuzných odvětví). Různé aspekty procesu „medikalizace“ je možné nahližet jako proces rozšiřování „pole“ působnosti lékařské autority a lékařského vědění (resp. postupného inkorporování oblastí lidského jednání, jež dosud do „medikálního pole“ nenáležely). Analýza expertního diskurzu a dobových rozhodovacích procesů poukazuje na symbiózu, resp. konflikt, (lékařského) systému vědění („režimu pravdy“) s jinými systémy vědění (zejména teologickým). Toto profesionalizující se společenství se opět propojuje s městským prostředím zejména v oblasti kontroly; v dobové terminologii je to především „zdravotní policie“ (medizinische 
Polizey). Jejím cílem je postupné utváření „sanitárního prostoru“ jako místa bezpečného pro zdraví. Kromě systému „sanitárních kordonü“ a zdravotních pasů, které měly zabránit širrení nákazy v dané oblasti/zemi a tím chránit obyvatelstvo na úrovni celozemské (turecká hranice pro celou monarchii), usilovaly státně byrokratické orgány v součinnosti s univerzitními „experty“ o likvidaci a odsouvání potenciálně nebezpečných „miazmatických“ zdrojů (jatka, mrchoviště, hřbitovy) z frekventovaných veřejných míst i o přijímání bezpečnostních opatření (protipožární, protiúrazové raády; zákazy koupání atd.) za účelem ochrany lidského zdraví.

Dalším výsledkem této spolupráce napojené i na experty $\mathrm{z}$ dalších oblastí vědění (stavební/civilní inženýři apod.) byla nejprve ve velkých městech (př́ílad Praha) celková úprava urbánního prostoru jako „bezpečného“ místa, kde jsou možné zdroje nebezpečí a nákazy jasně lokalizovány a kontrolovány (výstavba nemocničního komplexu na Karlově a promyšlení jeho zásobování vodou, větrání apod. - spolupráce s ing. Hergetem; budování důmyslné pražské kanalizace propojující celé město (1790-1824), rovněž zejména dílo Ing. Hergeta; systém osvětlování ulic; dláždění napojené kanalizaci a systém odpadu apod.). Přirozeně se nabízí otázka, jak se tento systém, původně vytvořený pro velká města, uplatňoval ve městech menších, resp. na venkově, který nebyl považován za tak „rizikovou“ oblast. Některé zmíněné aspekty by bylo vhodné studovat na zvláštním typu měst, totiž měst lázeňských, která se právě v tomto období rozvíjela a kde právě lékařská autorita a „moc“ plnila funkci zcela specifickou (navíc byla často napojena i na kontrolní orgány policie). Navíc právě z lázeňských měst se zachovala celá řada „zdravotních topografií, které se dosud nestaly předmětem historiografického zájmu. Jan Zdichynec očekává i zde vliv antického dědictví, at už v rovině medicíny, či architektonické inspirace.

V Evropě v drtivé většině studujeme historická města, jež jsou výsledkem staletého vrstvení. Richard Biegel tuto situaci vidí jako nedílnou součást jejich charakteru a identity. Společným atributem je na jedné straně kontinuita projevující se v hluboké provázanosti jednotlivých etap a fenoménů, na druhé naopak stř̌etávání a prolínání různorodých protikladů, které vyvrcholilo v posledních dvou staletích a které $\mathrm{z}$ historických měst učinilo pozoruhodnou laboratoř, jež názorně zrcadlí překotné změny společnosti a její identity, které se během této doby udály. Stávají se tak tématem pro výzkum zejména hmotného kulturního dědictví par excellence.

Protikladem dramatického společenského vývoje se stala památková ochrana měst, která se $\mathrm{v}$ průběhu 20. století postupně zformulovala a která dokázala uchovat jejich hmotnou podstatu i v př́padě, že se jejich reálný obsah radikálně proměnil. Historická města se tak stala nejen symbolickým středem městských aglomerací, ale také nositelem identity a kontinuity, jež z reálného života mnohdy zcela zmizela (viz historická města v Sudetech, $\mathrm{v}$ dnešním západním Slezsku). Ocenění památkové hodnoty měst můžeme konstatovat jako obecně evropský jev, připomíná Luda Klusáková, v jehož kontextu praxe chránění celých komplexů formou městských rezervací byla výsledkem úsilí expertů, jimž se podařilo tuto, ve své době unikátní, strategii prosadit.

Richard Biegel zdůrazňuje, že památkové rezervace se tak staly místem, kde se památková hodnota slévá s identitou místa a jeho obyvatel, kde se minulost mísí s každodenností a kde se vize budoucnosti nutně stř̌etávají s požadavkem za zachování historického charakteru místa. Tato zvláštní symbióza činí z historických měst úhelný kámen našeho kulturního dědictví: nikde jinde není jeho přítomnost zakoušena intenzivněji a nikde jinde 
nemusí být jeho smysl promýšlen a obhajován častěji než právě v centrech historických měst, jež jsou zároveň středobodem městského života jako takového.

Právě tento moment je východiskem interdisciplinárního výzkumu, jehož cílem je nejen porozumění proměnám identity a interpretace historických měst, ale také charakteristika jejich současné pozice v lokálním i celospolečenském kontextu optikou strategického užívání kulturního dědictví [Klusáková - Ozouf-Marignier 2017].

K úvahám o výzkumné ose soustředěné na městskou problematiku se přidává Jaroslav Ira. Vychází z pojetí města jakožto sociálně organizovaného prostoru [Musil 2002], když se zamýšlí nad adaptačními procesy, které nahlíží především optikou malého města v kontextu modernity. Z hlediska systémové teorie lze malé město chápat jako systém, jenž existuje v určitém prostředí. Vývoj v rámci prostředí, jež zahrnuje dílčí systémy (např. hodnotový systém, politický systém, trh, systémy vědění) vytvárí podněty k adaptaci malého města, přičemž adaptace zpětně ovlivňují prostředí, resp. systémy jej tvořící [Luhmann 2006]. Pokud posuneme pozornost $\mathrm{k}$ aktérům, kteří disponují věděním a/nebo mocí rozhodovat (experti, technokraté, inteligence, kulturní elity, policy-makeři, historikové), pak můžeme téma adaptace malého města uchopit jako otázku po vymezování systému, prostředí a jejich vztahu. Př́slušný aktér vymezuje a interpretuje systém (malé město / malá města obecně), definuje a vytváří obrazy relevantního prostředí (např. historický kontext jeho vývoje; výzvy a př́ležitosti) a také povahu jejich vzájemného vztahu (např. míru autonomie vưči prostředí, strukturální limity a možnosti smysluplné akce v malém městě atd.).

V kontextu soudobých diskuzí o rozvoji či revitalizaci malých měst a obecněji dalšího vývoje západní společnosti se rozvinulo široké bádání o malých městech např. na poli regionálních a rozvojových studií, sociální geografie, ekonomie či studia turismu a kulturního dědictví. Většina tohoto výzkumu však setrvává v analýze přítomnosti, resp. projektování budoucnosti, aniž by zohlednila dlouhodobou a obecnou perspektivu historického vývoje, a to nejen malých měst samotných, nýbrž především kulturních, myšlenkových, ideologických, mentálních či emocionálních rámců, které vymezovaly místo malého města v moderní a postmoderní epoše. Právě na tato podloží je třeba se podle Jaroslava Iry zaměřit, a to v časové perspektivě zhruba od 16. do 21. století, doporučuje Jan Zdichynec. Ačkoliv se jedná zdánlivě jen o ideovou „nadstavbu“, ve skutečnosti je jejich úloha zásadní. Obrazy malého města nejsou jen produktem strukturální proměny prostoru v industriální a postindustriální epoše, v níž se velké město stává hegemonem [Lefebvre 1991], nýbrž také kulturním předpokladem jejich dalšího vývoje. Jde totiž o to, že vedle diskurzů, které se explicitně vztahují k malému městu (obraz maloměsta v literatuře, kritické eseje o maloměstské mentalitě, expertní texty o vhodné architektuře pro malá města), se malé město stává - často jen implicitním - prvkem v obecných a více či méně směrodatných diskurzech a konceptech moderní a postmoderní společnosti. Analýza těchto útvarů z perspektivy malého města nejenže přinese lepší porozumění podmínkám jeho rozvoje, ale podle Irova názoru otevře jednu $\mathrm{z}$ dalších cest pro dekonstrukci myšlenkových schémat moderní a postmoderní společnosti, ve kterých mají své podstatné místo také samotné dichotomie město a venkov [Williams 1973], resp. velké město a malé město.

V obecné rovině jsou obzvláště zajímavé konstrukce, které lze chápat jako utváření myšlenkových rámců. Abychom rozkryli myšlenkové rámce adaptačních strategií, je třeba se zaměřit nejen na intelektuální a expertní diskurzy o malém městě, ale také na chápání malého města ze strany aktérů, kteří reprezentují spíše vnitřní, emický pohled z malých 
měst (např. místní inteligence), což snad bude v dílčích případech možné již na příkladě malých měst Lužic a Slezska. $V$ neposlední řadě lze tyto myšlenkové rámce zpětně vyčíst také z konkrétních adaptačních strategií a projektů, které odkazují nap̌r. na hlubší představy o povaze urbanity či o vztahu města a venkova. Utváření městského prostoru má svá regionální specifika a kořeny již v době předmoderní, doplňuje Jan Zdichynec.

Sociálně historický př́stup posouvá Linda Kovářová $\mathrm{k}$ antropologické perspektivě, která nám umožní postihnout operacionalizaci historických př́íladů $\mathrm{v}$ regionálních a malo-městských strategiích. Nedílnou součástí adaptačních procesů navázaných na urbánní prostředí jsou rovněž transfery a adaptace „velké“ městské kultury v rurálním prostředí „malých“ měst a vesnic. Jedním z př́íladů je již zmíněný fenomén tzv. neo-rurálů. Ve společenských vědách se o neo-rurálech hovoří jako o společenském hnutí, které má počátky v Evropě v 60. letech 20. století, kdy se rostoucí počet lidí začal z městských oblastí stěhovat na venkov. Tyto provenkovské migrace samotný venkov proměnily jak materiálně, tak symbolicky - ustanovením určitého životního stylu a definováním společné identity, navázáním nových vztahů a vytvořením nové komunity a nových společenských vazeb či přivlastněním si nového místa, území nebo kulturního dědictví. Neo-rurálové zahrnují široké spektrum lidí, $v$ jehož rámci můžeme vnímat odlišnost jednotlivých profilů, a proto lze mluvit také o různých kategoriích a typech neo-rurálů - například ty, kteří na venkově pouze bydlí, ale většinu dne tráví ve městě, kde pracují a na kterém jsou závislí, oproti těm, kteří se svých vazeb na město vzdají a většina jejich aktivit probíhá ve venkovském prostředí. Neo-rurálové do venkovského prostředí přenášejí ekonomický, společenský či kulturně inovační kapitál nabytý ve městech, jehož prostřednictvím ovlivňují stávající strukturu rurálního prostředí. Řada neo-rurálů je zároveň představiteli tzv. kulturních kreativců [Ray - Anderson 2000] nebo též tzv. třídy kreativců [Florida 2002]. Pojmenování cultural creatives (kulturní kreativci) pochází od amerického sociologa Paula H. Raye a psycholožky Sherry Ruth Andersonové a slouží k popisu velké části západní společnosti, jež stojí mimo standardní paradigma modernistů (progresivních) versus tradicionalistů (konzervativních) a která zakládá nový typ kultury. Kulturní kreativci často poukazují na limity stávajících systémů, snaží se otevř́t mnohostranný dialog a přicházejí s novými myšlenkami, vizemi, hodnotami, nástroji a modely jak řešit současné ekologické, ekonomické, sociální, kulturní a náboženské problémy. Obdobný pohled přináší Richard Florida, který hovoří o vzniku nové společenské třídy creative class (trrída kreativců) [Florida 2002]. V českém prostředí se vybraného segmentu neo-rurálů / kulturních kreativců dotkl dlouholetý výzkum ekologicky příznivých forem životního způsobu Katedry environmentálních studií Fakulty sociálních studií Masarykovy Univerzity, vedený socioložkou Hanou Librovou, z něhož vzešla trilogie Pestři a zelení [1994], Vlažní a váhaví [2003] a Věrní a rozumní [2016].

$\mathrm{Na}$ základě perspektiv artikulovaných na předchozích stránkách rozvinuli Hana Červinková a Zdeněk Uherek zmíněné antropologické hledisko. V něm se jako významný jeví zejména vztah mezi kulturním dědictvím $v$ městském prostředí a identitami (identifikacemi) v jejich historických, politických a sociokulturních dimenzích a kontextech. Kulturní dědictví lze chápat jako „způsoby, kterými se vybrané historické materiální artefakty, př́rodniny, mýty, vzpomínky a tradice stávají kulturními, politickými a ekonomickými činiteli současnosti“ [Graham - Howard 2008]. Identity jsou pak vnímány jako procesy stále probíhající adaptace, to znamená jako reakce na globální toky, které se střetávají 
v urbánních centrech [Appadurai 1996], a jakožto vytváření lokálních významů sounáležitosti a hledání svého místa ve světě. $\mathrm{V}$ tomto kontextu se stává kulturní dědictví mnohovýznamovou kategorií, která nám umožňuje prozkoumávat, jak jednotlivci a diferencovaná společenství lidí spojují významy př́tomnosti a minulosti konkrétními (materiálními nebo nehmotnými) místy a koncepty při konstruování jejich vlastních kulturních identit: „To, jak označujeme, kam jsme zařazováni a zařazujeme sami sebe prostřednictvím narativů minulosti“ [Hall 1993]. Antropologický př́stup ke studiu kulturního dědictví, alespoň tak, jak ho vnímají Hana Červinková a Zdeněk Uherek, směřuje ke studiu průniků odlišných a často soupeřících nároků na kulturní dědictví, s nimiž se jednotlivci chtějí identifikovat: prolínají se zde transnacionální (globální) policyscapes univerzálního dědictví, oficiální státní a lokální politika a potřeby jednotlivých aktérů tváří v tváŕ těmto oficiálním kodifikovaným narativům. Antropology, ale jistě též i další specializace zajímají soupeřící a vzájemně se odlišující identifikační prostředí, na diverzifikovaná místa přináležitosti a paměti ve snaze porozumět, jak jsou hegemonní diskurzy kulturního dědictví překládány, používány, přetvářeny př́ípadně negovány jednotlivci i komunitami v lokálních podmínkách. Výzvou může být otázka, jak hluboko v historii lze tyto postuláty sledovat např. prostřednictvím ego dokumentů. Pomocí etnografického výzkumu se dá pak zjištovat, jak jednotliví aktéŕi vytvářejí město zároveň jako sociopolitický a symbolický konstrukt [Harvey 1989; Brenner - Theodore 2002; Graham - Howard 2008] a prostor každodenního života [De Certeau 1984; Hall 1993; Herzfeld 1991]. Př́klady takového výzkumu mohou zahrnovat: hegemonní a marginalizované identity v politikách kulturního dědictví ve střední Evropě; neoliberalismus a pamět středoevropských měst; „ti druzí "v městském prostředí, kodifikované a personalizované významy dávané a odnímané prvkům kulturního dědictví.

V neposlední řadě Zdeněk Uherek doplňuje aspekt vyplývající z výzkumů migrací a kontaktních situací mezi diferencovanými společenskými skupinami. Při šetřeních tohoto typu se pojem adaptace dlouhodobě používal jako součást slovníku, $v$ němž figurovaly též pojmy asimilace, akulturace, integrace či koexistence. Teorie spojené s těmito koncepty již zpočátku 20. století reflektovaly, že vủči mechanismům přizpůsobení vznikají též odezvy rezistence, protestu, vytváření kontrakultur. Adaptace má vždy též svůj maladaptivní protipól nebo protipól kulturní alternativy. $\mathrm{V}$ českém prostředí jsou etnografie rezistence sbírané od dob protireformace stejně bohaté jako dějiny konformismu, a tento aspekt se týká i významů vztahovaných ke kulturnímu dědictví, které může být $\mathrm{v}$ jeho veřejně artikulované podobě pro jednotlivce současně skvělým obchodem a současně eticky velmi komplikovanou tematikou. Dědictví některých rodin či diaspor může být ve své podstatě protichůdné kulturnímu dědictví konceptualizovanému současnými technokraty.

\section{Závěr}

Formulovat závěry na samém počátku projektu je nepochybně ošidné. Při pohledu zvenčí se už samotné zveřejnění iniciální diskuze, ze které vzešly, jeví jako riskantní krok. Přesto si myslíme, že takový počin má smysl. Reflektovaná „synchronizace“ badatelských perspektiv se totiž zdá být pro řešitelský tým nezbytným krokem při konstrukci projektu a formulování výzkumných otázek. Pro početný a především víceoborový tým představuje první krok v hledání a identifikaci tematických průniků, př́buzných teoretických 
pozic a komplementárních metodologických přístupů. Jinak by stěží bylo možné rozvinout výzkum v ad hoc vznikajících pracovních skupinách okolo čtyř konceptuálních os a směřovat k synergii.

Již v této počáteční fázi je zřetelně patrné, že výzkum procesů expertního řízení se bude nutně protínat s výzkumem využívání a reprezentace kulturního dědictví. Nebở prosazování inovací či určitých přístupů k organizaci a využívání veřejného prostoru, resp. ke kulturnímu dědictví ve veřejném prostoru, se odvíjí od sociálních rolí expertů a dalších zainteresovaných aktérů. Jejich skladba, společenská pozice i formy interakce se přitom v čase proměňovaly, což podtrhuje význam historické perspektivy. Kromě věcných výzkumných záměrů si projekt klade ještě jeden další cíl. Badatelé v humanitních vědách tradičně pracují každý sám, izolováni v „bublinách“ svých témat. Ideální ambicí projektu je tuto uzavřenost překonat a vytvořit platformu pro interdisciplinární týmovou práci, nebở společné psaní je v humanitních vědách stále ještě ojedinělým jevem, častěji se objevuje ve vědách sociálních. Očekáváme tedy, že spolupráce mezi antropology a historiky může být v tomto směru inspirativní v dalších etapách projektu právě tak, jako byla podnětná tato zkušenost formulování pozičního dokumentu ve formátu diskuze u kulatého stolu.

\section{Literatura}

Anderson, Benedict [1983]. Imagined Communities: Reflections on the Origin and Spread of Nationalism. London: Verso.

Augé, Marc [1992]. Non-lieux: introduction à une anthropologie de la surmodernité. Paris: Seuil.

Appadurai, Arjun [1996]. Modernity at Large. Cultural Dimensions of Globalization. Minneapolis: University of Minnesota Press.

Ashworth, G. J. - Graham, Brian - Tunbridge, J. E. [2007]. Pluralising Pasts: Heritage, Identity and Place in Multicultural Societies. London - Ann Arbor: Pluto Press.

Audrerie, Dominique [1997]. La notion et la protection du patrimoine. Vol. 3304. Paris: Presses universitaires de France.

Barth, Fredrik [1993]. Enduring and Emerging Issues in the Analysing of Ethnicity. In. Vemerleuen, Han - Govers, Cora (ed.). The Anthropology of Ethnicity. Amsterdam: Het Spinhuis, s. 12-32.

Bhabha, Homi K. [1994]. The Location of Culture. London - New York: Routledge.

Blažek, Jiří - Uhlí̌, Jan [2011]. Teorie regionálního rozvoje. Nástin, kritika, implikace. Praha: Karolinum.

Blyth, Mark [2002]. Great Transformations: Economic Ideas and Institutional Change in the Twentieth Century. Cambridge: Cambridge U.P.

Bobková, Lenka - Fantysová-Matějková, Jana (ed.) [2013]. Terra - Ducatus - Marchionatus - Regio. Die Bildung und Entwicklung der Regionen im Rahmen der Krone des Königreichs Böhmen. Die Kronländer in der Geschichte des böhmischen Staates VI. Prag: Casablanca.

Bokova, Irina [2013]. „Prologue“. Basic Texts of the 2005 Convention on the Protection and Promotion of the Diversity of Cultural Expressions. Paris: UNESCO.

Borneman, John - Ghassem-Fachandi, Parvis [2017]. The concept of Stimmung: From indifference to xenophobia in Germany's refugee crisis. Hau: Journal of Ethnographic Theory 7 (3): 105-135.

Brenner, Neil - Nik, Theodore (ed.) [2002]. Spaces of Neoliberalism: Urban Restructuring in North America and Western Europe. Malden, Ma: Blackwell.

Brubaker, Rogers [2000]. Beyond Identity. Theory and Society 29: 1-47.

Brubaker, Rogers [2004]. Ethnicity without groups. Cambridge, Mass.: Harvard University Press.

Burke, Peter [1992]. History and Social Theory. Cambridge: Polity Press.

Cameron, Cristina [2008]. From Warsaw to Mostar: The World Heritage Committee and Authenticity. APT Bulletin 39 (2/3): 19-24. 
Calligaro, Oriane [2014]. Negotiating Europe: Eu Promotion of Europeanness Since the 1950s. New York: Palgrave Macmillan.

Certeau, Michel de [1984]. The Practice of Everyday Life. Berkeley: University of California Press.

Clark, Peter [2009]. European Cities and Towns (400-2000). Oxford: Oxford University Press.

Cline, Eric H. [2008]. Troy as a „Contested Periphery“: Archaeological Perspectives on Cross-Cultural and Cross-Disciplinary Interactions Concerning Bronze Age Anatolia. In. Collins, Billie Jean - Bachvarova, Mary R. - Rutherford, Ian C. (ed.). Anatolian Interfaces: Hittites, Greeks and Their Neighbours. Proceedings of an International Conference on Cross-Cultural Interaction, September 17-19, 2004, Emory University, Atlanta, GA. Oxford: Oxbow Books, s. 11-19.

Červinková, Hana - Buchowski, Michal, - Uherek, Zdeněk, et al. [2015]. Rethinking Ethnography in Central Europe. New York: Palgrave.

Červinková, Hana - Golden, Juliet [2017]. The Containment of Memory in the „Meeting Place“: City Marketing and Contemporary Memory Politics in Central Europe. In. Krase, Jerome - Uherek, Zdeněk, et al. Diversity and Local Contexts: Urban Space, Borders and Migration. New York: Palgrave Macmillan, s. 55-70.

Delafons, John [1997]. Politics and Preservation. A policy history of the built heritage 1882-1996. Oxford: Chapman and Hall.

Dufková, Marie - Ondřejová, Iva (ed.) [2004]. Historie sběratelství antických památek v českých zemích. Editio Monographica Musei Nationalis Pragae 2. Praha: Národní muzeum.

Édouard, Jean-Charles [2012]. La place de la petite ville dans la recherche géographique en France: de la simple monographie au territoire témoin. Annales de géographie 1 (683): 25-42. Dostupné z: https:// www.cairn.info/revue-annales-de-geographie-2012-1-page-25.htm.

Édouard, Jean-Charles [2008]. La petite ville: contexte scientifique et enjeux de développement /aménagement. Bulletin de l'Association de géographes français 85 (1): 3-12. Dostupné z: http://www .persee.fr/doc/bagf_0004-5322_2008_num_85_1_2592.

Eley, Geoff [2005]. A Crooked Line: From Cultural History to the History of Society. Ann Arbor: University of Michigan Press.

Elias, Norbert [1978]. What is sociology?. New York: Columbia University Press.

Falser, Michael [2005]. Cultural Heritage as Civilizing Mission: Methodological Considerations. In. Falser, Michael (ed.). Cultural Heritage as Civilizing Mission. Transcultural Research - Heidelberg Studies on Asia and Europe in a Global Context. Springer: Cham, s. 1-32.

Florida, Richard [2002]. The Rise of Creative Class. New York: Basic Books.

Florida, Richard [2005]. Cities and the creative class. London, New York: Routledge.

Florida, Richard [2017]. The New Urban Crisis. Gentrification, housing bubbles, growing inequality, and what we can do about it. London: Oneworld Publications.

Gellner, Ernest [1997]. Nationalism. New York: New York University Press.

Gellner, Ernest [1983]. Nations and Nationalism. Ithaca: Cornell University Press.

Gellner, Ernest [1998]. Language and Solitude. Wittgenstein, Malinowski and Habsburg Dilemma. Cambridge: Cambridge University Press.

Girella, Luca - Pavúk, Peter [2016]. The Nature of Minoan and Mycenaean Involvement in the North-eastern Aegean. In. Gorogianni, Evi - Pavúk, Peter - Girella, Luca (ed.). Beyond Thalassocracies. Understanding Processes of Minoanisation and Mycenaeanisation in the Aegean.Oxford: Oxbow Books, s. $15-42$.

Gosden, Chris [2004]. Archaeology and Colonialism. Cultural Contact from 5000 BC to the Present. Cambridge: Cambridge U.P.

Gravari-Barbas, Maria [2009]. La „ville festive“ ou construire la ville contemporaine par l'événement. (The „Festival City“: urban events and contemporary city building). Bulletin de l'Association de géographes français 86 (3): 279-290. Dostupné z: http://www.persee.fr/doc /bagf_0004-5322_2009_num_86_3_2673.

Graf, Klaus [1984]. Gmünder Chroniken im 16. Jahrhundert: Texte und Untersuchungen zur Geschichtsschreibung der Reichsstadt Schwäbisch Gmünd. Schwäbisch Gmünd: Einhorn-Verlag. 
Graham, Brian - Howard, Peter [2008a]. Heritage and Identity. In. Graham, Brian - Howard, Peter (ed.). The Ashgate research companion to heritage and identity. Burlington: Ashgate Publishing Company, s. $1-15$.

Graham, Brian - Howard, Peter (ed.) [2008b]. The Ashgate research companion to heritage and identity. Burlington: Ashgate.

Hall, Stuart [1993]. Cultural Identity and Diaspora. In. William, Patrick - Chrisman, Laura (ed.). Colonial Discourse \& Postcolonial Theory: A Reader. New York: Columbia University Press, s. 392-403.

Hannerz, Ulf [1992]. The Global Ecumene as a Network of Networks. In. Kuper, Adam (ed.). Conceptualizing Society. London: Routledge, s. 34-58.

Hannerz, Ulf [1996]. Transnational Connections: Culture, People, Places. London: Routledge.

Harc, Lucyna - Wąs, Gabriela (ed.) [2014]. The Strengthening of Silesian Regionalism (1526-1740). (Cuius regio. Ideological and Territorial Cohesion of Silesia 2). Wrocław: Publishing House eBooki.com.pl.

Harvey, David [1989]. From Managerialism to entrepreneurialism: The Transformation in Urban governance in Late Capitalism. Geografiska Annaler: Series B, Human Geography 71 (1): 3-17.

Harvey, David C. [2008]. History of Heritage. In. Graham, Brian - Howard, Peter (ed.). The Ashgate research companion to heritage and identity. Burlington: Ashgate, s. 19-36.

Herzfeld, Michael [1991]. A Place in History. Social and Monumental Time in a Cretan Town. Princeton: Princeton University Press.

Herzfeld, Michael [1997]. Cultural Intimacy: Social Poetics in the Nation State. London, New York: Routledge.

Hietala, Marjatta [1993]. La diffusion des innovations: Helsinki 1875-1917. Genèses, 10, Municipalismes, sous la direction de Alban Bensa: 74-89.

Halbwachs, Maurice. [1980]. The collective memory. First published 1952. New York: Harper and Row.

Hobsbawm, Eric [1991]. Nations and Nationalism Since 1780: Programme, Myth, Reality. Cambridge: Cambridge University Press.

Hroch, Miroslav [1985, 2000]. Social Preconditions of National Revival in Europe: A Comparative Analysis of the Social Composition of Patriotic Groups among the Smaller European Nations. Cambridge: Cambridge University Press. a 2. vyd. New York: Columbia University Press.

Chevalier, Michel [1993]. Neo-rural phenomena. In: Espace géographique. Espaces, modes demploi. Two decades of l'Espace géographique, an anthology. Special issue in English 1993 (1), s. 175-191. Dostupné z: http://www.persee.fr/doc/spgeo_0046-2497_1993_hos_1_1_3201.

Ira, Jaroslav - Kalivodová, Eva - Klusáková, Luda - Larguèche, Aladin - Moll, Martin - Sargent, Andrew (ed.) [2010]. Crossing Frontiers, Resisting Identities. Pisa: Edizioni Plus, Pisa University Press.

Jha, Abhas K. - Miner, Todd W. - Stanton-Geddes, Zuzana (ed.) [2013]. Building urban resilience: principles, tools, and practice. Washington, DC: World Bank.

Kayser, Bernard [1990] La renaissance rurale. Sociologie des campagnes du monde occidental. Paris: Armand Colin.

Kayser, Bernard [2001]. Les citadins au village. Espace, populations, sociétés 2001 (1-2), Repopulation et mobilités rurales: $151-160$.

Kłodziński, Marek [2006]. Aktywizacja społeczno gospodarcza gmin wiejskich i małych miast, Instytut rozwoju wsi i rolnictwa. Warszawa: PAN.

Klusáková, Luda [2008]. Between Urban and Rural Culture: Public Use of History and Cultural Heritage in Building Collective Identities (1990-2007). In. Klusáková, Luda - Teulières, Laure (ed.). Frontiers and Identities. Cities in Regions and Nations. Pisa: Edizioni Plus, Pisa University Press, s. 299-322.

Klusáková, Luda - Ozouf-Marignier, Marie-Vic [2017]. Small Towns as a European Cultural Heritage. Introduction. In. Klusáková, Luda, et al. Small Towns in Europe in the 20th and 21st Centuries. Heritage and Development Strategies. Prague: Karolinum, s. 11-23.

Kocka, Jürgen [1999]. Industrial Culture and Bourgeois Society: Business, Labor, and Bureaucracy in Modern Germany, 1800-1918. New York - Oxford: Berghahn Books.

Koziura, Karolina [2017]. Colonial Factors Hidden in City Center Revitalization: Chernivtsi as an Imperial Formation. In. Krase, Jerome - Zdeněk Uherek, et al. Diversity and Local Contexts: Urban Space, Borders and Migration. New York: Palgrave Macmillan, s. 93-109.

Kuper, Adam [1988]. The Invention of Primitive Society: Transformations of an Illusion. London: Routledge. Labadi, Sophia - Long, Colin (ed.) [2010]. Heritage and Globalisation. London - New York: Routledge. 
Landry, Charles - Wood, Phil [2008]. The Intercultural City. Planning for Diversity Advantage. London Sterling, VA: Earthscan.

Landry, Charles [2008]. The Creative City. A Toolkit for Urban Innovators. 2. vyd. London - Sterling, VA: Comedia Earthscan.

Landry, Charles [2006]. The Art of Citymaking. London - Sterling, VA: Comedia Earthscan.

Lefebvre, Alain [1987]. Aujourd'hui, la culture du monde rural. Toulouse (podle B. Kayser, Renaissance rurale, 1990).

Lefebvre, Alain - Boure, Robert [2000]. La médiation culturelle du territoire: l'exemple de trois festivals en milieu rural. Sud-Ouest européen, Géographies culturelles (8): 49-56. Dostupné z: https://www.persee .fr/doc/rgpso_1276-4930_2000_num_8_1_2739.

Lefebvre, Henri [1974]. La production de l'espace. Paris: Anthropos.

Lefebvre, Henri [1991]. Production of Space. Oxford, Cambridge: Blackwell.

Mainet, Hélène [2011]. Les petites villes françaises en quête d’identité. Ambiguïté du positionnement ou image tactiquement combinée?. Mots. Les langages du politique [online], 2011 (97). Dostupné z: https:// journals.openedition.org/mots/20514.

Marcus, George [1998]. Ethnography through Thick and Thin. Princeton, NJ: Princeton University Press.

Mountjoy, P.A. [1998]. The East Aegean-West Anatolian Interface in the Late Bronze Age: Mycenaeans and the Kingdom of Ahhiyawa. Anatolian Studies 48: 33-67.

Müller, Birgit - Uherek, Zdeněk (ed.) [1996]. Všední den v Jablonci roku 1994. Wien: Verein Internationales Forschungszentrum Kulturwissenschafte.

Musil, Jiř́ [2002]. Co je Urbanizace. In. Horská, Pavla - Maur, Eduard - Musil, Jiří. Zrod velkomèsta. Urbanizace českých zemí a Evropa. Praha - Litomyšl: Paseka, s. 13.

Périgois, Samuel [2008]. La mobilisation du champ patrimonial dans l'élaboration d'une identité „petite ville“. (Heritage and identity strategies in small-sized Cities). Bulletin de l'Association de géographes français 85 (1):23-32. Dostupné z: https://www.persee.fr/doc/bagf_0004-5322_2008_num_85_1_2594.

Radaelli, Claudio M. [2008]. Technocracy in the European Union. London: Longman.

Rau, Susanne [2002]. Geschichte und Konfession. Städtische Geschichtsschreibung und Erinnerungskultur im Zeitalter von Reformation und Konfessionalisierung in Bremen, Breslau, Hamburg und Köln. Hamburg - München: Dölling und Galitz.

Ray, Paul H. - Anderson, Sherry Ruth [2000]. The Cultural Creatives: How 50 Million People Are Changing the World. New York: Three Rivers Press.

Robertson, Roland [1995]. Glocalization: Time-Space and Homogeneity-Heterogeneity. In. Featherstone, Mike - Lash, Scott - Robertson, Roland (ed.). Global Modernities. London: Sage publications; New Delhi: Thousand Oaks, s. 25-44.

Sachse, Carola [1993]. Siemens, der Nationalsozialismus und die moderne Familie. Eine Untersuchung zur sozialen Rationalisierung in Deutschland im 20. Jahrhundert. Hamburg: Rasch und Röhring Verlag.

Said, Edward [1978]. Orientalism. New York: Pantheon Books.

Sibertin-Blanc, Mariette [2008]. Différenciation territoriale et enjeux d'aménagement des petites villes. Lexemple de l'action culturelle. (Territorial differentiations and issues of development in small-sized cities: the example of cultural policies). Bulletin de l'Association de géographes français 85 (1): 43-53. Dostupné z: http://www.persee.fr/doc/bagf_0004-5322_2008_num_85_1_2596.

Silverman, Helaine - Waterton, Emma - Watson, Steve [2017]. Heritage in Action: Making the Past in the Present. Cham: Springer international.

Smith, Laurajane [2006]. Uses of Heritage. New York: Routledge.

Sonkoly, Gábor [2015]. Cultural Heritage, in Bridge over troubled waters? The link between European historical heritage and the future of European Integration. European Commission: 14-19.

Stockhammer, Philipp W. [2013]. From Hybridity to Entanglement, from Essentialism to Practice. Archaeological Review from Cambridge 28 (1): 11-28.

Svasek, Maruska [2012] Emotions, Emotives and Political Negotiations: Transforming Relationships in the Bohemian-Bavarian Border Zone. In. Svasek, Maruska (ed.). Emotions and Mobility: Ethnographies of Movement. London - New York: Routledge, s. 145-162.

Šubrt, Jiří [2008]. „Dialog mezi hluchými“? K problematice vztahu sociologie a historie / „A Dialogue between the Deaf"? The Relationship between Sociology and History. Sociologický Časopis / Czech Sociological Review 44 (5), Monotematické číslo Proměny teoretické sociologie: 969-988. 
Uherek, Zdeněk [2011]. Diversity and Social Anthropology. In. Knottler, Steven - De Lobel, Rob - Tsipouri, Lena - Stenius, Vanja (ed.). Diversity Research and Policy. Amsterdam: Pallas, Amsterdam University Press, s. 21-41.

Uherek, Zdeněk [2017]. Discourse on Public Spaces: Praguers in the Process of Globalization Changes and the Neoliberal Economy. In. Krase, Jerome - Uherek, Zdeněk, et al. Diversity and Local Contexts: Urban Space, Borders and Migration. New York: Palgrave Macmillan, s. 93-109.

Vleuten, Erik - Oldenziel, Ruth - Davids, Mila - Lintsen, Harry [2017]. Engineering the Future, Understanding the Past: A Social History of Technology. Amsterdam: AUP.

Wagner, Peter [1995]. Soziologie der Moderne: Freiheit und Disziplin. Frankfurt am Main: Campus.

Wagner, Peter [2008]. Modernity as Experience and Interpretation. New Sociology of Modernity. Cambridge: Polity Press.

Wagner, Peter - Strath, Bo [2017]. European Modernity: A Global Perspective. London, Bloomsbury. Williams, Raymond [1973]. The Country and the City. New York: Oxford UP.

Wolf, Eric [1982]. Europe and the People Without History. Berkeley: University of California Press.

U kulatého stolu diskutovali:

Richard Biegel, KREAS / Filozofická fakulta Univerzity Karlovy, richard.biegel@ff.cuni.cz

Hana Červinková, KREAS / Filozofická fakulta Univerzity Karlovy, Uniwersytet Dolnośląski, Wroclaw, hana.cervinkova@ff.cuni.cz

Jaroslav Ira, KREAS / Filozofická fakulta Univerzity Karlovy, jaroslav.ira@f.cuni.cz

Jiří Janáč, KREAS / Filozofická fakulta Univerzity Karlovy, Ústav pro soudobé dějiny AV ČR, jiri.janac@ff.cuni.cz

Lud’a Klusáková, KREAS / Filozofická fakulta Univerzity Karlovy, luda.klusakova@f.cuni.cz

Linda Kovářová, KREAS / Filozofická fakulta Univerzity Karlovy, Anthropictures s.r.o, linda .kovarova@ff.cuni.cz

Tomáš Masař, KREAS / Filozofická fakulta Univerzity Karlovy, tomas.masar@ff.cuni.cz

Peter Pavúk, KREAS / Filozofická fakulta Univerzity Karlovy, peter.pavuk@ff.cuni.cz

Jakub Rákosník, KREAS / Filozofická fakulta Univerzity Karlovy, jakub.rakosnik@ff.cuni.cz Jan Randák, KREAS / Filozofická fakulta Univerzity Karlovy, jan.randak@ff.cuni.cz

Vitězslav Sommer, KREAS / Filozofická fakulta Univerzity Karlovy, Ústav pro soudobé dějiny $A V \check{C} R$, vitezslav.sommer@ff.cuni.cz

Matěj Spurný, KREAS / Filozofická fakulta Univerzity Karlovy, Ústav pro soudobé dějiny $A V \check{C} R$, matej.spurny@ff.cuni.cz

Radka Šustrová, KREAS / Filozofická fakulta Univerzity Karlovy, Ústav pro soudobé dějiny $A V \check{C} R$, radka.sustrova@ff.cuni.cz

Daniela Tinková, KREAS / Filozofická fakulta Univerzity Karlovy, daniela.tinkova@ff.cuni.cz

Zdeněk Uherek, Institut sociologických studií, Fakulta sociálních věd Univerzity Karlovy, zdenek.uherek@fsv.cuni.cz

Jan Zdichynec, KREAS / Filozofická fakulta Univerzity Karlovy, jan.zdichynec@ff.cuni.cz 